GUIMARÃES, MA; GARCIA, MFN; TELLO, JPJ; LEMOS NETO, HS; LIMA NETO, BP; RABELO, JS. 2019. Tomato grafting on rootstock of Jilo, Cocona and Jurubeba. Horticultura Brasileira 37: 138-145. DOI - http://dx.doi.org/10.1590/S0102-053620190203

\title{
Tomato grafting on rootstock of Jilo, Cocona and Jurubeba
}

\section{Marcelo de A Guimarães' ${ }^{1} \mathbb{D}$; Manuel Filipe N Garcia' $\mathbb{D}^{\mathbb{D}}$; Jean Paulo de J Tello ${ }^{3 \mathbb{D}}$; Hozano de S Lemos Neto ${ }^{4 \mathbb{D}}$; Benedito P Lima Neto ${ }^{1} \mathbb{D}$; Janiquelle da S Rabelo ${ }^{1 \mathbb{D}}$}

${ }^{1}$ Universidade Federal do Ceará (UFC), Fortaleza-CE, Brazil; mguimara@ufc.br; benepneto@hotmail.com; rabelojs@hotmail.com; ${ }^{2}$ Escola Municipal Santo Expedito, Tonantins-AM, Brazil; tonantas@yahoo.com.br; ${ }^{3}$ Universidade Federal de Viçosa (UFV), Viçosa-MG, Brazil; jp jt@ hotmail.com; ${ }^{4}$ Universidade Federal Rural do Semi-Árido (UFERSA), Mossoró-RN, Brazil; hozanoneto@hotmail.com (corresponding author)

\begin{abstract}
Grafting has been considered an important tool to produce tomato in adverse environments. Therefore, the aim of this study was to develop grafting protocols for tomato on rootstocks of Jilo, Cocona and Jurubeba. The work was carried out in a randomized block design, in a factorial scheme $(3 \times 2)+1$ with three grafting methods (slant-cut grafting, cleft grafting and splice grafting), combined with two graft ages and rootstocks (depending on the species), and the control. The rootstocks for tomato (Solanum lycopersicum) cv. Santa Clara were: 1) Jilo (S. gilo) cv. Comprido Grande Rio; 2) Cocona (S. sessiliflorum) and 3) Jurubeba ( $S$. jamaicense). The methods were individually studied and the graft length (GL); chlorophyll 'a' and chlorophyll ' $b$ ' in pre and post-grafting; graft diameter (GD), pre-grafting and tissue union of the grafted individuals through the assignment of grades were evaluated. Seven days after grafting, evaluations of grafted plants were performed. It was possible to establish a grafting protocol for all the combinations. The rootstock of Cocona provided greater vigor to 'Santa Clara' tomato graft. The cleft grafting technique can be indicated as the most effective for tomato grafting on the studied Solanaceae species.
\end{abstract}

Keywords: Solanum lycopersicum, cleft grafting, propagation, fresh tomato.

\section{RESUMO}

Enxertia do tomateiro sobre porta-enxertos de jiló, cubiu e jurubeba

A enxertia tem sido citada por inúmeros pesquisadores como importante ferramenta a ser adotada para a produção de tomateiro em ambientes com condições adversas para a cultura. Baseado nisso, objetivou-se desenvolver protocolos de enxertia para o tomateiro sobre porta-enxertos de jiló, cubiu e jurubeba. O trabalho foi conduzido no delineamento em blocos ao acaso, em esquema fatorial $(3 \times 2)+1$, sendo três métodos de enxertia (bisel com grafite, fenda cheia e inglês simples), combinados com duas idades de enxertos e porta-enxertos (dependendo da espécie), além do pé-franco. Os porta-enxertos para o tomateiro (Solanum lycopersicum) cv. Santa Clara foram: 1) jiloeiro (S. gilo) cv. Comprido Grande Rio; 2) cubieiro ( $S$. sessiliflorum) e 3) jurubebeira (S. jamaicense). Estes foram estudados individualmente, sendo avaliados os comprimentos do enxerto (CE); clorofila 'a' e clorofila 'b' em pré e pós-enxertia; diâmetro do enxerto (DE) em pré-enxertia e, pegamento dos indivíduos enxertados através da atribuição de notas. As avaliações das plantas enxertadas foram realizadas aos sete dias após a enxertia. Com base nos resultados obtidos foi possível estabelecer um protocolo de enxertia para todas as combinações avaliadas. Os porta-enxertos de cubieiro proporcionaram maior vigor ao enxerto de tomateiro 'Santa Clara'. A técnica fenda cheia pode ser indicada como a mais efetiva para a enxertia de tomateiro nas espécies de solanáceas estudadas.

Palavras-chave: Solanum lycopersicum, fenda cheia, propagação, tomate de mesa.

\section{Received on February 27, 2018; accepted on December 5, 2018}

$\mathrm{T}_{\mathrm{i}}$ omato (Solanum lycopersicum) is one of the main vegetables consumed in the world, being only after potato (S. tuberosum). In 2016, Brazil ranked ninth in the world ranking of tomato production with $4,167,629$ tons (FAO, 2016). From 2013 to 2017, there was an increase in tomato productivity from $66.8 \mathrm{t} \mathrm{ha}^{-1}$ to $68.7 \mathrm{t} \mathrm{ha}^{-1}$ (IBGE, 2017). Despite the significant results in recent years, there are important challenges to be faced to achieve greater productive efficiency.
Phytosanitary problems are one of the existing challenges, which, depending on the location of the plant, can be remedied through the application of pesticides (Santos \& Coltri, 1986; Vida et al., 2004). However, if such problems are present in the soil, these products may not be efficient in minimizing or solving the problem, making them difficult to control (Filgueira, 2013).

In the Brazilian Northeast, more specifically in areas of horticultural production in the state of Ceará, researchers from Embrapa Agroindustria Tropical surveyed the main pathogens affecting vegetables in the State. According to the researchers, Ralstonia solanacearum (bacterial wilt) and gall nematodes (Meloidogyne incognita and $M$. javanica) are characterized as the main pathogens and their greatest occurrences were observed in areas of tomato production (Freire et al., 2000).

Both diseases are difficult to control since the soil is the means of survival of pathogens and the main means 
of growing vegetables (Filgueira, 2013). However, despite the difficulties that may exist for controlling these pathogens, techniques were developed and technologies capable of overcoming such problems such as: a) soil treatment with chemical products (Santos \& Coltri, 1986; Vida et al., 2004); b) solarization (Baptista et al., 2007); c) use of resistant varieties (Vida et al., 2004; Lopes \& Quezado-Duval, 2007), and d) grafting (Vida et al., 2004; Lopes \& Quezado-Duval, 2007; Loos et al., 2009; Medeiros et al., 2011).

Grafting seems to be the one that provides the greatest advantages to vegetable producers (mainly tomato), who in general have problems with soil pathogens. This technique is harmless to the environment, provides quick results and does not alter the production system used by the producer. In grafting, two plants are joined anatomically and physiologically, growing as a single individual (Dickison, 2000).

Tomato grafting has been studied by several researchers in Brazil and abroad, and good results have been obtained for continuous tomato production in areas affected by different pathogens. For example, 'Anchor T' and BGH 3472 , resistant to $R$. solanacearum (Loos et al., 2009); 'Guardião', 'Helper-M', 'Magnet', 'He-Man', 'Kagemuscha' and 'Dr. K', resistant to Meloidogyne spp. (Cantu et al., 2009); "S. gilo (Raddi Jilo)" resistant to $R$. solanacearum (Medeiros et al., 2011); "S. toxicarum (Jurubebinha)" resistant to $R$. solanacearum (Santos \& Coltri, 1986) "S. sessiliflorum (Cocona)" resistant to $R$. solanacearum (Fernandes $\&$ Bentes, 2018).

Cocona is a branched and erect shrub that grows from 1 to $2 \mathrm{~m}$ height, being able to be cultivated in several types of soils of the Amazon, from the Zona da Mata of Pernambuco and in some locations of the Southeast region (Silva Filho, 1996).

Jurubeba is a native plant to Brazil, also in tropical regions of South America such as Paraguay, Bolivia and Argentina. Its roots, stems, leaves, flowers and fruits are used. In addition, it is widely used as medicine and in cooking (Garcia et al., 2008; Vieira Júnior et al., 2015).
The species $S$. gilo belongs to the Solanaceae family and is characterized as a branched shrub, fruiting in clusters from 2 to 4 fruits, that presents variable shape according to the cultivar, oblong, round or elongated, with thin bark, varied color and bitter taste (Pereira et al., 2012).

These Solanaceae have been identified as tolerant or resistant to several types of diseases, which makes their studies, as rootstocks, attractive from the technical-scientific point of view. Therefore, this work aimed to develop protocols of tomato grafting on rootstocks of Jilo, Cocona and Jurubeba.

\section{MATERIAL AND METHODS}

The research was carried out in a protected environment at the Department of Plant Science, Agricultural Sciences Center of the Federal University of Ceará, Campus Pici, in Fortaleza (343'02"S, 38 32'35' W, altitude 19.5 $\mathrm{m})$. The local climatic classification is 'As', rainy tropical (Alvares et al., 2013). The annual precipitation is $1,338 \mathrm{~mm}$, the minimum temperature is $23 \pm 2^{\circ} \mathrm{C}$ and the maximum is $30 \pm 2^{\circ} \mathrm{C}$.

The study was divided into four experiments, all conducted in a randomized complete block design with four replicates, 20 plants per plot. A factorial arrangement $(3 \times 2)+1$ was used with three grafting methods (slantcut grafting, cleft grafting and splice grafting) combined with two grafting ages.

Experiment I) Self-grafting in

\section{'Santa Clara' tomato}

Two grafting ages were studied [18 and 23 days after sowing, (DAS) for the graft plant] and (23 and 28 DAS for rootstock plant).

In all trials, the youngest grafts were grafted onto the youngest rootstocks (18/23 DAS, respectively), the same happening for the oldest grafts and rootstocks (23/28 DAS, respectively).

After being verified that grafting did not promote any type of alteration in the aspects observed in the self-grafted plants in relation to the self-rooted ones, we decided to use the self-rooted tomato as a comparative control for the other tests.

Experiment II) 'Santa Clara' tomato grafting on Jilo 'Comprido Grande Rio' (S. gilo)

In the first grafting date, graft and rootstock plants, were with 23 and 56 DAS, respectively, and in the second with 28 and 61 DAS, respectively.

Experiment III)'Santa Clara' tomato grafting on Cocona $(S$. sessiliflorum)

On the first grafting date, the graft and rootstock plants were with 17 and 58 DAS, respectively and on the second date with 28 and 67 DAS.

Experiment IV) Tomato grafting on Jurubebeira ( $S$. jamaicense)

On the first grafting date, the graft and rootstock plants were with 28 and 78 DAS, respectively, and in the second date with 33 and 83 DAS.

In all experiments, graftings were performed in grafts and rootstocks of the same age. The determination of the grafting age of each species took into account the development rate of the plants, focusing mainly on obtaining grafts in the shortest period, preferably when the seedlings of all species had about 3 to 4 definitive leaves.

Plant material and growing conditions

The production of seedlings, grafts and rootstocks for all experiments was carried out in a shelter environment with chapel-type ceiling covered with 125 $\mu \mathrm{m}$ anti-uv diffuser plastic film and $30 \%$ shade with their sides completely open. Polypropylene trays of 162 cells $\left(31 \mathrm{~cm}^{3}\right.$ per cell) were used to produce rootstock seedlings. To produce graft seedlings, trays of the same material were used, but with 200 cells $\left(18 \mathrm{~cm}^{3}\right.$ per cell).

All trays were filled with 2:1 substrate (organic compound : vermiculite). After filling the trays, two seeds were sown per cell. At seven DAS, seedlings were thinned, leaving only one plant per cell.

A micro-sprinkler system was used for seedlings irrigation, being activated twice a day, early in the morning and late in the afternoon, leaving the substrate at its maximum water retention capacity.

Plants with different ages were grafted (two dates), and then evaluated 
seven days after the grafts healing period. The total period from sowing to transplanting of the grafts was from 27 to 43 DAS, when the self-rooted plants presented about four to six leaves, which represents the ideal time for transplanting.

For all types of grafting, the grafts were detached from their root system using a surgical scalpel and the cutting for grafting was made approximately $1 \mathrm{~cm}$ below the cotyledon leaves. Rootstocks, grafts (Jiloeiro, Cocona and Jurubebeira) had their shoot parts totally removed to $1.0 \mathrm{~cm}$ above the cotyledonary leaves.

For splice grafting, graft and rootstock were cut at an approximate angle of $45^{\circ}$. The same procedure was performed for slant-cut grafting, but with the help of a scion of $1.0 \mathrm{~cm}$, half was inserted inside the stem of the graft and the remaining $0.5 \mathrm{~cm}$ in the stem of the rootstock.

For the cleft grafting, after being cut at an approximate angle of $90^{\circ}$, the rootstocks had their stems sectioned in the middle, from apex to base to $1.0 \mathrm{~cm}$ deep. The grafts that were used in this technique had the lateral parts of the stem removed, forming a kind of wedge.

After the completion of each grafting techniques and consequently the preparation of each graft composition, a silicone clip was used to maintain close contact between the cut parts of the different plants used. In addition, wood rods of approximately $30 \mathrm{~cm}$ were used to support the produced grafts.

Then, the new plant compositions were placed in a growth room, with controlled environment, with temperature close to $25 \pm 4^{\circ} \mathrm{C}$, relative humidity (RH) between 80 and $100 \%$ and fluorescent light of $72 \mathrm{~W}$ (two 36 W lamps), distant about $25 \mathrm{~cm}$ from the apex of the plants that supplied approximately 3000 lux. Treatments were submitted to a photoperiod of 12 hours light/dark. In this environment the grafts remained for seven days.

\section{Evaluated characteristics}

The evaluated characteristics in all experiments were: a) graft length $(\mathrm{GL}, \mathrm{cm})$, measured from the grafting point to the insertion point of the apical meristem; b) graft diameter (GD, mm); c) chlorophyll 'a' d) chlorophyll 'b' [the measurements of chlorophylls ' $a$ ' and ' $b$ ' were indirect, in a non-destructive way, through SPAD (Falker Ltda.), seven days after grafting]; e) grafting success [assignment of grades on the union of the rootstock/graft: 0 (no union), 1 (small union), 2 (partial union) and 3 (complete union)].

\section{Statistical analysis}

Data were submitted to analysis of variance; after the determination of differences between treatments by the F test, these were submitted to the Scott-Knott test for means comparison at 5\% significance. These analyzes were performed by Sisvar ${ }^{\circledR}$ software (Ferreira, 2011).

\section{RESULTS AND DISCUSSION}

\section{Tomato: Self-grafting x self-rooted}

There was no interaction between grafting methods and dates. Differences were observed for grafting ages, for grafting and self-grafting methods of 'Santa Clara' tomato.

Regarding the age of the plants, differences were observed for all evaluated factors. At age 18/23 DAS (graft/rootstock), the plants presented higher chlorophyll ' $a$ ' than those aged 23/28 DAS in the slant-cut grafting (Table 1). The length was smaller in splice grafting on $23 / 28$ DAS. Regarding the grafting methods, they influenced ' $a$ ' and ' $b$ ' chlorophylls, with emphasis to the cleft grafting technique, whose mean did not differ from the selfrooted control.

Treatments did not differ from each other for graft length, regardless of the plants age (Table 1).

Regarding the grade and the grafting success, with cleft grafting technique, the values were superior to those observed for the other grafting methods, obtaining $60 \%$ success in both grafting dates, without differentiating from the

Table 1. Means of chlorophyll 'a', chlorophyll ' $b$ ', graft length and success of individuals grafted from tomato 'Santa Clara' after self-grafting. Fortaleza, UFC, 2015.

\begin{tabular}{|c|c|c|c|c|c|}
\hline \multicolumn{6}{|c|}{ Chlorophyll 'a' (unit) } \\
\hline DAS & Splice grafting & $\begin{array}{c}\text { Slant-cut } \\
\text { grafting }\end{array}$ & $\begin{array}{c}\text { Cleft } \\
\text { grafting }\end{array}$ & $\begin{array}{l}\text { Self- } \\
\text { rooted }\end{array}$ & Mean \\
\hline $18 / 23$ & $21.23 \mathrm{bA}$ & $22.63 \mathrm{aA}$ & $23.00 \mathrm{aA}$ & $23.00 \mathrm{aA}$ & $22.46 \mathrm{~A}$ \\
\hline $23 / 28$ & $20.27 \mathrm{bA}$ & $20.37 \mathrm{bB}$ & $22.79 \mathrm{aA}$ & $23.83 \mathrm{aA}$ & $21.81 \mathrm{~A}$ \\
\hline Mean & $20.75 \mathrm{~b}$ & $21.50 \mathrm{~b}$ & $22.89 \mathrm{a}$ & $23.41 \mathrm{a}$ & \\
\hline \multicolumn{6}{|c|}{$\mathrm{CV}(\%)=5.94$} \\
\hline \multicolumn{6}{|c|}{ Chlorophyll 'b' (unit) } \\
\hline $18 / 23$ & $3.07 \mathrm{bA}$ & $3.51 \mathrm{aA}$ & $3.66 \mathrm{aA}$ & $3.44 \mathrm{aA}$ & $3.42 \mathrm{~A}$ \\
\hline $23 / 28$ & $2.77 \mathrm{bA}$ & $3.29 \mathrm{aA}$ & $3.44 \mathrm{aA}$ & $3.46 \mathrm{aA}$ & $3.24 \mathrm{~A}$ \\
\hline Mean & $2.92 \mathrm{~b}$ & $3.40 \mathrm{a}$ & $3.55 \mathrm{a}$ & $3.45 \mathrm{a}$ & \\
\hline \multicolumn{6}{|c|}{$\mathrm{CV}(\%)=10.09$} \\
\hline \multicolumn{6}{|c|}{ Graft length (GL.cm) } \\
\hline $18 / 23$ & $4.63 \mathrm{aA}$ & $4.49 \mathrm{aA}$ & $4.51 \mathrm{aA}$ & $4.86 \mathrm{aA}$ & $4.62 \mathrm{~A}$ \\
\hline $23 / 28$ & $3.97 \mathrm{aB}$ & $4.51 \mathrm{aA}$ & $4.01 \mathrm{aA}$ & $4.09 \mathrm{aA}$ & $4.15 \mathrm{~A}$ \\
\hline Mean & $4.30 \mathrm{a}$ & $4.50 \mathrm{a}$ & $4.26 \mathrm{a}$ & $4.47 \mathrm{a}$ & \\
\hline \multicolumn{6}{|c|}{$\mathrm{CV}(\%)=10.13$} \\
\hline \multicolumn{6}{|c|}{ Grafting success (\%) } \\
\hline $18 / 23$ & $1.86 \mathrm{cB}$ & $3.00 \mathrm{bB}$ & $5.00 \mathrm{aA}$ & $5.00 \mathrm{aA}$ & $3.71 \mathrm{~B}$ \\
\hline $23 / 28$ & $4.14 \mathrm{bA}$ & $4.14 \mathrm{bA}$ & $5.00 \mathrm{aA}$ & $5.00 \mathrm{aA}$ & $4.57 \mathrm{~A}$ \\
\hline Mean & $3.00 \mathrm{c}$ & $3.57 \mathrm{~b}$ & $5.00 \mathrm{a}$ & $5.00 \mathrm{a}$ & \\
\hline
\end{tabular}

$\mathrm{DAS}=$ days after sowing; Means followed by different lowercase letters in the rows and capital letters in the column, differ among themselves, Scott-Knott test $(5 \%)$. 


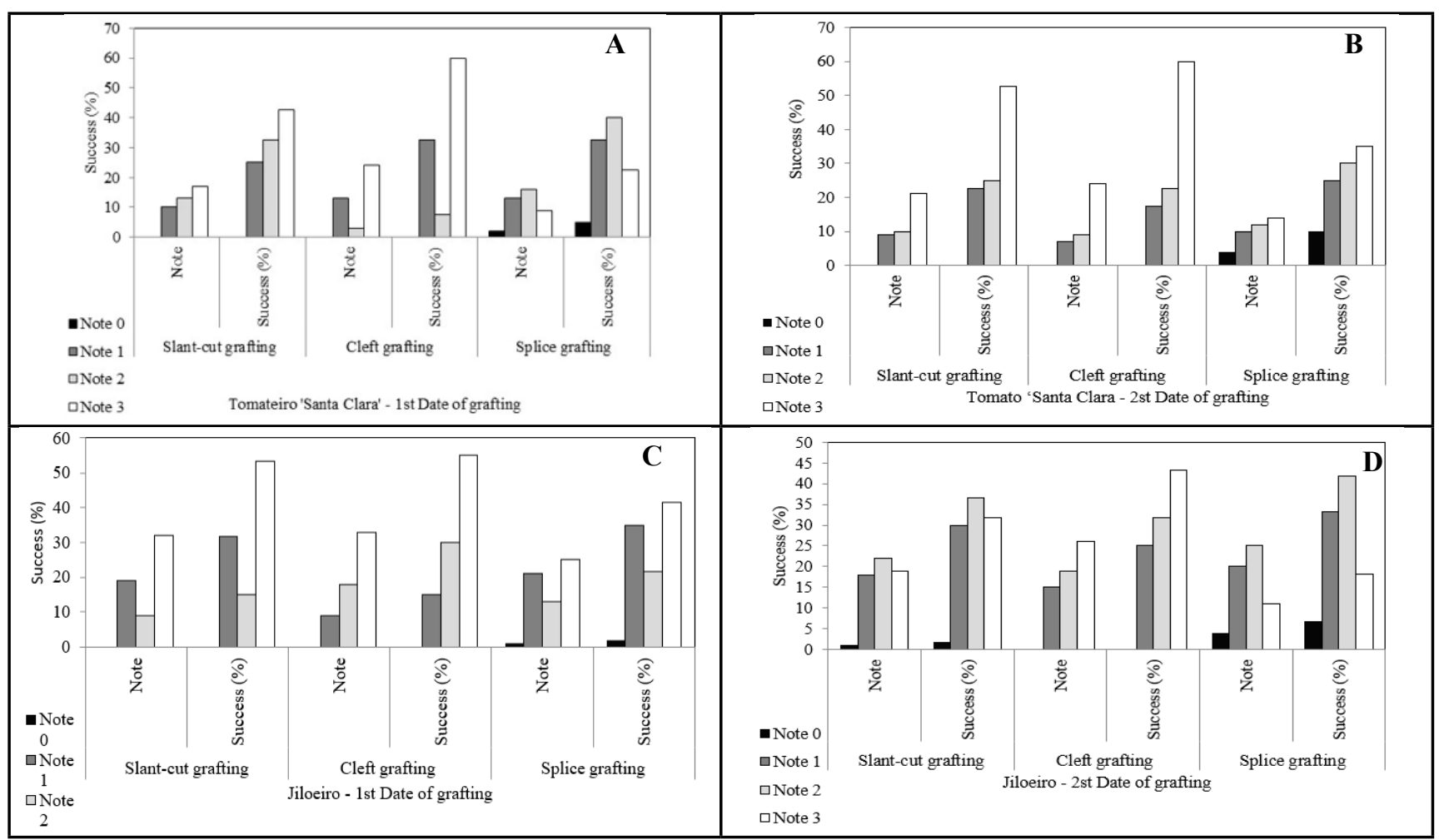

Figure 1. Percentage of score and success of grafted individuals. A: first grafting date (18/23 DAS); B: second grafting date (23/28 DAS) after being used in self-grafting processes (graft and rootstock, respectively); C: first grafting date (23/56 DAS); D: second grafting date (28/61 DAS), after being used in grafting processes on Jiloeiro (graft and rootstock, respectively). Fortaleza, UFC, 2015.

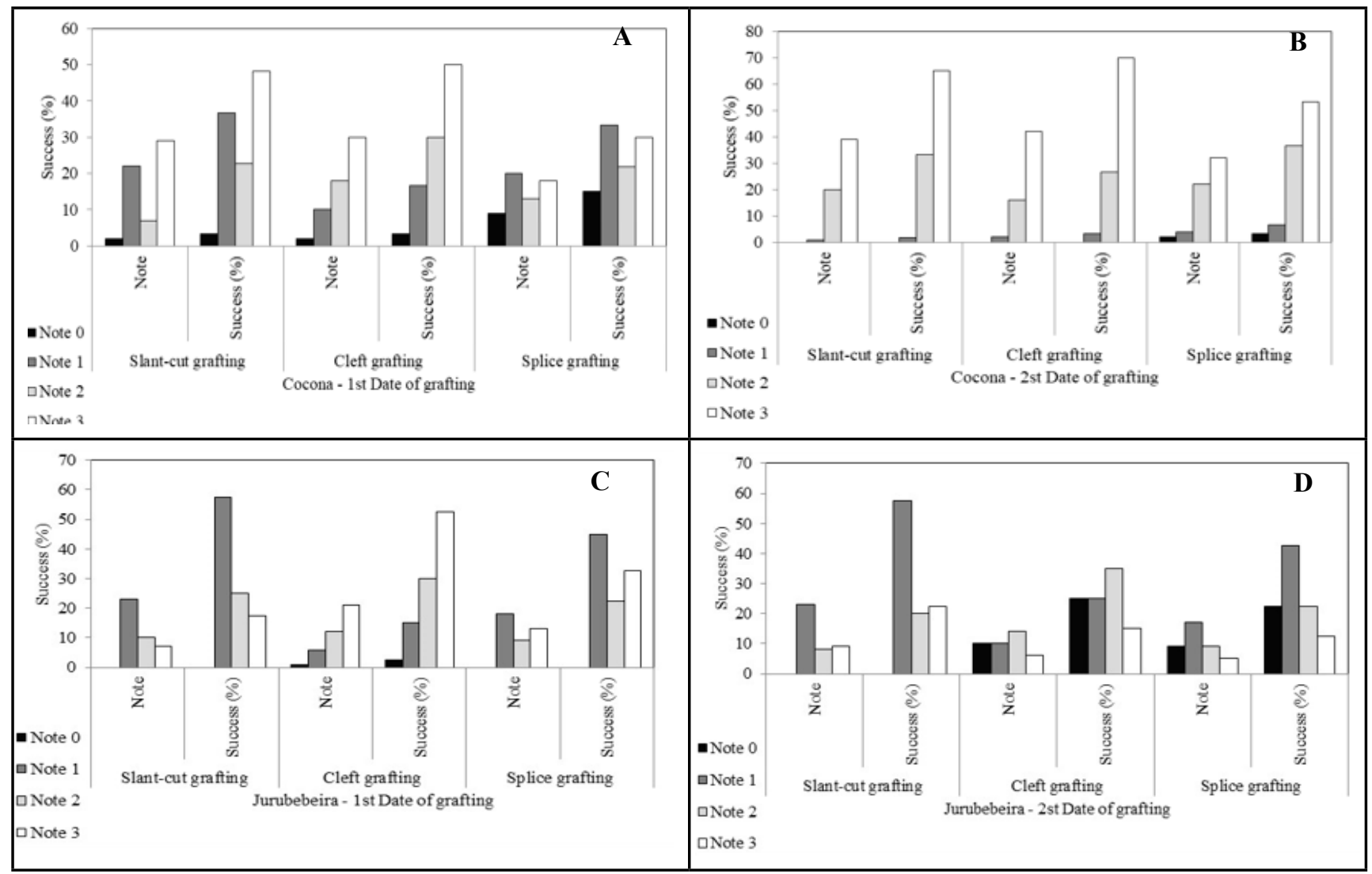

Figure 2. Percentages of grades and success of grafted individuals. A: first grafting date (23/56 DAS); B: second grafting date (28/61 DAS) (grafting and rootstock, respectively), after being used in the grafting processes on Cocona; C: first grafting date (28/78 DAS); D: second grafting date (33/83 DAS), after being used in grafting processes on Jurubebeira (graft and rootstock, respectively). 
self-rooted plants (Figures 1A, 1B).

It is important to point out that for the self-rooted plants, since they have not undergone any specific grafting treatment, it is always assumed, at least in this work, that their minimum score will always be three, which is characteristic of the maximum grafting success. Then, the self-rooted plants acted more as a positive control of effective comparison of the grafting techniques. Working with cucumber seedlings grafted on pumpkin, Stripari et al. (1997) observed high survival rates $(96.5$ and $100 \%)$ of the plants grafted by the cleft grafting technique, despite using a methodology different from that used in this work.

\section{Self-rooted tomato $x$ tomato} grafted on Jiloeiro

No difference was observed between the tomato plants used before the application of the grafting techniques. This result is important because it shows that there was uniformity between the plants used for the different treatments in the development of this work. In addition, it allows a more conclusive and accurate interpretation of the behavior of the grafts in relation to the bases (rootstocks), as well as in relation to the grafting techniques.

However, regarding the ages of the grafts, differences were observed for the stem diameter and graft length, with the highest means observed for grafts from older tomato plants at 28 DAS.

Seven days after grafting, the grafts and the self-rooted plants had their shoot parts evaluated again for possible effects of the grafting and rootstock methods on the shoot part of the tomato plants (grafts) (Table 2).

In Table 2, we observe a difference between the grafting treatments and the

Table 2. Means of chlorophyll ' $a$ ', chlorophyll ' $b$ ', graft length and grafting success of tomato 'Santa Clara' after being used on Jiloeiro grafts. Fortaleza, UFC, 2015.

\begin{tabular}{|c|c|c|c|c|c|}
\hline \multicolumn{6}{|c|}{ Chlorophyll 'a' (unit) } \\
\hline DAS & $\begin{array}{l}\text { Splice } \\
\text { grafting }\end{array}$ & $\begin{array}{l}\text { Slant-cut } \\
\text { grafting }\end{array}$ & Cleft grafting & Self-rooted & Mean \\
\hline $23 / 56$ & $21.86 \mathrm{aA}$ & $18.24 \mathrm{bA}$ & $22.70 \mathrm{aA}$ & $21.90 \mathrm{aA}$ & $21.17 \mathrm{~A}$ \\
\hline $28 / 61$ & 0.00 & 0.00 & $17.98 \mathrm{bB}$ & $21.38 \mathrm{aA}$ & $19.68 \mathrm{~A}$ \\
\hline Mean & $21.86 \mathrm{a}$ & $18.24 \mathrm{a}$ & $20.34 \mathrm{a}$ & $21.64 \mathrm{a}$ & \\
\hline \multicolumn{6}{|c|}{$\mathrm{CV}(\%)=12.26$} \\
\hline \multicolumn{6}{|c|}{ Chlorophyll 'b' (unit) } \\
\hline $23 / 56$ & $3.86 \mathrm{aA}$ & $3.08 \mathrm{bA}$ & $4.42 \mathrm{aA}$ & $3.96 \mathrm{aA}$ & $3.83 \mathrm{~A}$ \\
\hline $28 / 61$ & 0.00 & 0.00 & $2.54 \mathrm{aB}$ & $3.36 \mathrm{aA}$ & $2.95 \mathrm{~B}$ \\
\hline Mean & $3.86 \mathrm{a}$ & $3.08 \mathrm{a}$ & $3.48 \mathrm{a}$ & $3.66 \mathrm{a}$ & \\
\hline \multicolumn{6}{|c|}{$\mathrm{CV}(\%)=18.94$} \\
\hline \multicolumn{6}{|c|}{ Graft length (GL, cm) } \\
\hline $23 / 56$ & $4.62 \mathrm{aA}$ & $3.68 \mathrm{bA}$ & $4.74 \mathrm{aB}$ & $4.16 \mathrm{bA}$ & $4.30 \mathrm{~A}$ \\
\hline $28 / 61$ & 0.00 & 0.00 & $5.70 \mathrm{aA}$ & $3.78 \mathrm{bA}$ & $4.74 \mathrm{~A}$ \\
\hline Mean & $4.62 \mathrm{a}$ & $3.68 \mathrm{~b}$ & $5.22 \mathrm{a}$ & $3.97 \mathrm{~b}$ & \\
\hline \multicolumn{6}{|c|}{$\mathrm{CV}(\%)=13.82$} \\
\hline \multicolumn{6}{|c|}{ Grafting success (\%) } \\
\hline $23 / 56$ & $4.60 \mathrm{aA}$ & $3.80 \mathrm{bA}$ & $5.00 \mathrm{aA}$ & $5.00 \mathrm{aA}$ & $4.60 \mathrm{~A}$ \\
\hline $28 / 61$ & 0.00 & 0.00 & $4.00 \mathrm{bB}$ & $5.00 \mathrm{aA}$ & $4.50 \mathrm{~A}$ \\
\hline Mean & $4.60 \mathrm{a}$ & $3.80 \mathrm{~b}$ & $4.50 \mathrm{a}$ & $5.00 \mathrm{a}$ & \\
\hline \multicolumn{6}{|c|}{$\mathrm{CV}(\%)=13.87$} \\
\hline
\end{tabular}

self-rooted plants for chlorophyll 'a' and ' $b$ '. However, for the graft length, the plants from the splice grafting and cleft grafting were the ones that produced the largest grafts $(4.92 \mathrm{~cm}$, on average), without differing from each other, but from the self-rooted plants $(3.97 \mathrm{~cm})$ and slant-cut grafting $(3.68 \mathrm{~cm})$. This observation is important since it shows a possible more vigorous condition of the Jiloeiro as rootstock, influencing the tomato grafts. The promotion of this condition may favor the establishment of grafts in the field, positively altering its productive capacity as observed in some experiments developed with the use of grafting techniques among different species. According to Cañizares \& Goto (2002), grafted plants may have greater vigor, mainly due to the influence of the rootstock used.

Regarding the grafting success, seedlings generated from the splice and cleft grafting techniques presented the highest means in the score parameter, not differentiating among themselves, nor from the self-rooted (Table 2). However, in relation to the grafting success, the cleft grafting technique provided 55 and $43.3 \%$, respectively, in the two grafting ages (Figures 1C, 1D).

Researchers, using Jiloeiro as rootstock on the cleft grafting technique, also observed high grafting success, 95 to $98 \%$, on varieties studied in grafted plants (Medeiros et al., 2011). Grafting tomato on Jiloeiro rootstock, Simões et al. (2014) also obtained satisfactory results, using single and double cleft methods, with $91.7 \%$ success for both techniques.

The combination of 23/56 DAS (graft/rootstock) age of grafted plants was the only one that made it possible to obtain plants for all grafting methods. For the 28/61 DAS combination, only plants submitted to the cleft grafting technique survived, which generally presented lower results than the selfrooted plants with the same age (Table 2).

Based on the results, for the success score of the grafted individuals, there is excellent compatibility between the two species and cultivars studied (Figures 1C, 1D), at least under the edaphoclimatic conditions of this work. 
The good affinity and compatibility observed between the tomato plant and the Jiloeiro may have occurred mainly because both species belong to the same genus, being their taxonomic proximities important in the healing process and graft formation (Farias $e t$ al., 2013).

Self-rooted tomato $x$ tomato grafted on Cocona

The tomato grafts used did not differ among themselves, nor of the shoot part of the self-rooted plants. These results are important because they show homogeneity among the tomato 'Santa Clara' produced for the grafting. In addition, it allows a more conclusive and accurate interpretation of the behavior of the grafts in relation to the bases (rootstocks), as well as in relation to the grafting techniques used.

Regarding the ages of the grafts, a difference was observed for the diameter and length of the graft. For chlorophylls ' $a$ ' and ' $b$ ' no differences were observed between the self-rooted treatments.

Seven days after grafting, the grafts and shoot part of the self-rooted plants were evaluated again for the effect of grafting techniques and the effect of rootstock on the graft (Table 3). No influence of rootstock or grafting methods on 'a' chlorophyll content was verified.

However, a difference for chlorophyll ' $b$ ', graft length and grafting success was observed between treatments. Slant-cut grafting and cleft grafting were those that provided the highest means of length, being even greater than the mean of the self-rooted plants.

This result is important because it shows a possible direct effect of force provided by the rootstock in the graft. This result indicates that there may be a transfer of possible endogenous factors from the root system of Cocona plants to the grafts, which were more vigorous than the shoot part of the self-rooted plants.

The cleft grafting method was the one that presented superior results, compatible with those observed for the self-rooted plants, in this case used as a control (Figures 2A, 2B). Cleft grafting presented better results at 23/56 and 28/61DAS, respectively, with $50 \%$ and

Table 3. Means of chlorophyll 'a', chlorophyll ' $b$ ', graft length and grafting success of individuals grafted from tomato 'Santa Clara' after being used as grafts on Cocona. Fortaleza, UFC, 2015.

\begin{tabular}{|c|c|c|c|c|c|}
\hline \multicolumn{6}{|c|}{ Chlorophyll 'a' (unit) } \\
\hline DAS & $\begin{array}{c}\text { Splice } \\
\text { grafting }\end{array}$ & $\begin{array}{c}\text { Slant-cut } \\
\text { grafting }\end{array}$ & $\begin{array}{c}\text { Cleft } \\
\text { grafting }\end{array}$ & $\begin{array}{c}\text { Self- } \\
\text { rooted }\end{array}$ & Mean \\
\hline $17 / 58$ & $22.76 \mathrm{aA}$ & $23.34 \mathrm{aA}$ & $21.44 \mathrm{aA}$ & $23.78 \mathrm{aA}$ & $22.83 \mathrm{~A}$ \\
\hline $28 / 67$ & $20.56 \mathrm{aA}$ & $20.34 \mathrm{aB}$ & $19.84 \mathrm{aA}$ & $23.00 \mathrm{aA}$ & $20.93 \mathrm{~B}$ \\
\hline Mean & $21.66 \mathrm{a}$ & $21.84 \mathrm{a}$ & $20.64 \mathrm{a}$ & $23.39 \mathrm{a}$ & \\
\hline \multicolumn{6}{|c|}{$\mathrm{CV}(\%)=10.46$} \\
\hline \multicolumn{6}{|c|}{ Chlorophyll 'b' (unit) } \\
\hline $17 / 58$ & $3.60 \mathrm{aA}$ & $3.80 \mathrm{aA}$ & $3.10 \mathrm{bB}$ & $4.22 \mathrm{aA}$ & $3.68 \mathrm{~A}$ \\
\hline $28 / 67$ & $3.50 \mathrm{bA}$ & $3.50 \mathrm{bA}$ & $4.08 \mathrm{aA}$ & $4.40 \mathrm{aA}$ & $3.87 \mathrm{~A}$ \\
\hline Mean & $3.55 \mathrm{a}$ & $3.65 \mathrm{a}$ & $3.59 \mathrm{a}$ & $4.31 \mathrm{a}$ & \\
\hline \multicolumn{6}{|c|}{$\mathrm{CV}(\%)=13.99$} \\
\hline \multicolumn{6}{|c|}{ Graft lenght (GL, cm) } \\
\hline $17 / 58$ & $3.50 \mathrm{bA}$ & $4.16 \mathrm{aA}$ & $4.16 \mathrm{aA}$ & $2.76 \mathrm{cA}$ & $3.64 \mathrm{~A}$ \\
\hline $28 / 67$ & $3.56 \mathrm{bA}$ & $4.48 \mathrm{aA}$ & $4.10 \mathrm{aA}$ & $2.76 \mathrm{cA}$ & $3.72 \mathrm{~A}$ \\
\hline Mean & $3.53 \mathrm{~b}$ & $4.32 \mathrm{a}$ & $4.13 \mathrm{a}$ & $2.76 \mathrm{c}$ & \\
\hline \multicolumn{6}{|c|}{$\mathrm{CV}(\%)=10.62$} \\
\hline \multicolumn{6}{|c|}{ Grafting success (\%) } \\
\hline $17 / 58$ & $5.0 \mathrm{aA}$ & $5.0 \mathrm{aA}$ & $5.0 \mathrm{aA}$ & $5.0 \mathrm{aA}$ & $5.0 \mathrm{~A}$ \\
\hline $28 / 67$ & $3.0 \mathrm{bB}$ & $3.0 \mathrm{bB}$ & $5.0 \mathrm{aA}$ & $5.0 \mathrm{aA}$ & $4.0 \mathrm{~B}$ \\
\hline Mean & $4.0 \mathrm{~b}$ & $4.0 \mathrm{~b}$ & $5.0 \mathrm{a}$ & $5.0 \mathrm{a}$ & \\
\hline
\end{tabular}

$\mathrm{CV}(\%)=13.38$

Means followed by different lowercase letters in the rows and capital letters in the column, differ among themselves, Scott-Knott test (5\%).

$70 \%$ success (Figures 2A, 2B). These results were similar to those obtained by Zeist et al. (2017), who also observed a higher rate of grafting success when using the combination of this species with the cleft grafting technique.

Regarding different ages of plants used for the composition of the grafts, their influence on graft length was not verified. However, for chlorophyll ' $a$ ' and grafting success, the combination of ages 17/58 DAS (graft/rootstock) was the one that presented the best results (Table 3). According to Santos \& Coltri (1986), the fact that Cocona is a solanaceous native to the Amazon region, rustic and resistant to soil diseases makes it an important species to be studied as rootstock.

Self-rooted tomato $x$ tomato grafted on Jurubebeira

For the pre-grafting characteristics, no differences between treatments were observed. These results show once again the high uniformity between the tomato seedlings used in the test, either for the preparation of the grafts, or for the establishment of the self-rooted plants. In addition, it allows a more conclusive and accurate interpretation of the graft's behavior in relation to the bases (rootstocks), as well as in relation to the grafting techniques used.

After 7 days, the grafts and the shoot part of the self-rooted plants were evaluated according to their treatments (Table 4). Among the grafting techniques used, once again the cleft grafting was the one that made it possible to obtain the best results, in general, similar to those observed for the self-rooted.

None of the plants which used the slant-cut grafting survived, showing a greater sensitivity of the Jurubebeira rootstock to this technique when compared to all other evaluated rootstocks. Such sensitivity may be related to the position and quantity 
Table 4. Means of chlorophyll ' $a$ ', chlorophyll ' $b$ ', graft length and grafting success from tomato 'Santa Clara' after being used as grafts on Jurubebeira. Fortaleza, UFC, 2015.

\begin{tabular}{|c|c|c|c|c|c|}
\hline \multicolumn{6}{|c|}{ Chlorophyll 'a' (unit) } \\
\hline DAS & $\begin{array}{c}\text { Splice } \\
\text { grafting }\end{array}$ & $\begin{array}{l}\text { Slant-cut } \\
\text { grafting }\end{array}$ & $\begin{array}{c}\text { Cleft } \\
\text { grafting }\end{array}$ & $\begin{array}{l}\text { Self- } \\
\text { rooted }\end{array}$ & Mean \\
\hline $28 / 78$ & $20.36 \mathrm{aA}$ & 0.00 & $23.60 \mathrm{aA}$ & $20.98 \mathrm{aA}$ & $21.65 \mathrm{~A}$ \\
\hline $33 / 83$ & 0.00 & 0.00 & 0.00 & $19.38 \mathrm{aA}$ & $19.38 \mathrm{~A}$ \\
\hline Mean & $20.36 \mathrm{a}$ & 0.00 & $23.60 \mathrm{a}$ & $20.18 \mathrm{a}$ & \\
\hline \multicolumn{6}{|c|}{$\mathrm{CV}(\%)=16.26$} \\
\hline \multicolumn{6}{|c|}{ Chlorophyll 'b’ (unit) } \\
\hline $28 / 78$ & $2.96 \mathrm{bA}$ & 0.00 & $4.08 \mathrm{aA}$ & $3.10 \mathrm{bA}$ & $3.38 \mathrm{~A}$ \\
\hline $33 / 83$ & 0.00 & 0.00 & 0.00 & $2.82 \mathrm{aA}$ & $2.82 \mathrm{~A}$ \\
\hline Mean & $2.96 \mathrm{~b}$ & 0.00 & $4.08 \mathrm{a}$ & $2.96 \mathrm{~b}$ & \\
\hline \multicolumn{6}{|c|}{$\mathrm{CV}(\%)=20.77$} \\
\hline \multicolumn{6}{|c|}{ Graft length (GL, cm) } \\
\hline $28 / 78$ & $5.98 \mathrm{aA}$ & 0.00 & $6.58 \mathrm{aA}$ & $5.20 \mathrm{aA}$ & $5.92 \mathrm{~A}$ \\
\hline $33 / 83$ & 0.00 & 0.00 & 0.00 & $4.52 \mathrm{aA}$ & $4.52 \mathrm{~B}$ \\
\hline Mean & $5.98 \mathrm{a}$ & 0.00 & $6.58 \mathrm{a}$ & $4.86 \mathrm{~b}$ & \\
\hline \multicolumn{6}{|c|}{$\mathrm{CV}(\%)=19.18$} \\
\hline \multicolumn{6}{|c|}{ Grafting success (\%) } \\
\hline $28 / 78$ & $4.20 \mathrm{bA}$ & 0.00 & $5.00 \mathrm{aA}$ & $5.00 \mathrm{aA}$ & $4.78 \mathrm{~A}$ \\
\hline $33 / 83$ & 0.00 & 0.00 & 0.00 & $5.00 \mathrm{aA}$ & $5.00 \mathrm{~A}$ \\
\hline Mean & $4.20 \mathrm{~b}$ & 0.00 & $5.00 \mathrm{a}$ & $5.00 \mathrm{a}$ & \\
\hline
\end{tabular}

$\mathrm{CV}(\%)=13.05$

$\mathrm{DAS}=$ days after sowing; Mean zero means no union from grafted plants. Means followed by different lowercase letters in the rows and capital letters in the column, differ among themselves, Scott-Knott test (5\%).

of vascular bundles in this species in relation to the others. This occurs because, when grafting is carried out, scion is inserted in the center of the stem axis of both the graft and the rootstock, which damages at least partially the vascular bundles and may prevent the arrival of the substances necessary for the healing and establishment of the graft.

Regarding different ages of plants used for the composition of the grafts, no surviving plants were observed, regardless of the grafting technique used, for the composition of older plants (33/83 DAS). For the compositions formed by younger plants (28/78 DAS), the best result was for the cleft grafting.

As observed, grafting presented $52.5 \%$ success with maximum success score (3) for the cleft grafting technique on the first grafting date (Figure 2C).

Researches about grafting of tomato IPA-6 "Saladete" and rootstock
Jurubebão and Red Jurubeba, in different grafting methods, observed a $83.3 \%$ adhesion rate for the double slit technique for Jurubebão rootstock. For red Jurubeba (rootstock), the cleft grafting technique provided the best results with $83.3 \%$ in relation to the others (Simões et al., 2014).

Like the Cocona, Jurubebeira is also a native plant of the Amazon region, being considered a rustic solanaceous, with potential to be used as rootstock, since it has qualities of rusticity, vigorous root system and is resistant to soil diseases (Santos \& Coltri, 1986).

It was possible to establish a grafting protocol for all grafting combinations, with better results for the cleft grafting technique in younger seedlings, for graft and rootstock conditions. Rootstocks from Jiloeiro and Cocona plants provided greater vigor to tomato 'Santa Clara' grafts, in combinations of grafts with ages 23/56 and 17/58 DAS, respectively, adopting the cleft grafting method.

\section{ACKNOWLEDGEMENTS}

The authors thank FAPEAM for granting scholarships to the second and third authors; to Conselho Nacional de Desenvolvimento Científico e Tecnológico (CNPq): HS Lemos Neto (PDJ- Proc. 154458/2018-0); MA Guimarães (DT- Proc.306062/20160 ); BP Lima Neto (GM); JS Rabelo (GD); and to Fundação Cearense de Apoio ao Desenvolvimento Cientifico e Tecnológico (FUNCAP) for financial support.

\section{REFERENCES}

ALVARES, CA; STAPE, JL; SENTELHAS, PC; GONÇALVES, JLM; SPAROVEK, G. 2013. Koppen's climate classification map for Brazil. Meteorologische Zeitschrift 22: 711-728.

BAPTISTA, MJ; REIS JUNIOR, FB; XAVIER, GR; ALCÂNTARA, C; OLIVEIRA, AR; SOUZA, RB; LOPES, CA. 2007. Eficiência da solarização e biofumigação do solo no controle da murcha-bacteriana do tomateiro no campo. Pesquisa Agropecuária Brasileira 42: 933-938.

CAÑIZARES, KAL; GOTO, R. 2002. Comparação de métodos de enxertia em pepino. Horticultura Brasileira 20: 95-99.

CANTU, RR; WILCKEN, SRS; ROSA, JMO; GOTO, R. 2009. Reação de porta-enxertos comerciais de tomateiro a Meloidogyne mayaguensis. Summa Phytopathologica 35: 216-218.

DICKISON, WC. 2000. Integrative plant anatomy. San Diego: Hartcourt Academic Press. 533p.

FAO - Food and Agriculture Organization. 2016. Available www.fao.org/faostat/es\#data/QC. Accessed November 15, 2018.

FARIAS, EAP; FERREIRA, RLF; ARAÚJO NETO, SE; COSTA, FC; NASCIMENTO, DS. 2013. Organic production of tomatoes in the Amazon region by plants grafted on wild Solanum rootstocks. Ciência e Agrotecnologia 37: 323-329.

FERNANDES, BS; BENTES, JLS. 2018. Enxertia de tomateiro em solanáceas silvestres no controle da murcha bacteriana. Revista Agrária Acadêmica 1: 26-32.

FERREIRA, DF. 2011. Sisvar. A Computer statistical analysis system. Ciencia e Agrotecnologia 35: 1039-1042.

FILGUEIRA, FAR. 2013. Novo manual de olericultura: agrotecnologia moderna na produção e comercialização de hortaliças. Viçosa: UFV. 421p. 
FREIRE, FCO; SANTOS, AA; VIANA, FMP. 2000. Doenças de plantas horticolas recentemente constatadas na Serra de Ibiapaba. Fortaleza: Embrapa Agroindústria Tropical.Comunicado Técnico 43: 1-5.

GARCIA, J; JACOBSON, TKB; FARIAS, JG; BOAVENTURA, RF. 2008. Effectiveness of methods to increase the germination rate of jurubeba (Solanum paniculatum L.) seeds. Pesquisa Agropecuária Tropical 38: 223-226.

IBGE - Instituto Brasileiro de Geografia e Estatística. 2017. Produção agrícola municipal (PAM). Rio de Janeiro: IBGE44:1-8.

LOOS, RA; CALIMAN, FRB; SILVA, DJH. 2009. Enxertia, produção e qualidade de tomateiros cultivados em ambiente protegido. Ciência Rural 39: 232-235.

LOPES, CA; QUEZADO-DUVAL, AM. 2007. Manejo de doenças bacterianas em tomateiro. In: SILVA, DJH; VALE, FXR (eds). Tomate: tecnologia de produção. Visconde de Rio Branco: Suprema. p.233-255.

MEDEIROS, JA; ARAÚJO, DM; VEIGA, F. 2011. Controle de murcha bacteriana por meio da enxertia de tomate com jiló no município de Rio Branco-AC. Cadernos de Agroecologia6: $1-4$.

PEREIRA, RB; PINHEIRO, JB; GUIMARÃES, JA; REIS, A. 2012. Doenças e pragas do jiloeiro. Circular Técnica 106. Brasília-DF.

SANTOS, JR; COLTRI, ML. 1986. Reação de solanáceas à murcha bacteriana do tomateiro. Embrapa. Comunicado Técnico 44: 1-6.

SILVA FILHO, DF. 1996. Orientações técnicas para o cultivo do cubiu (Solanum sessiliflorum Dunal) na Amazônia. Manaus: INPA. 9p.

SIMÕES, AC; ALVES, GEB; FERREIRA, RLF; ARAÚJO NETO, SE; ROCHA, JF. 2014. Compatibilidade de tomateiro sob diferentes porta-enxertos e métodos de enxertia em sistema orgânico. Enciclopédia Biosfera 10: 961-972.

STRIPARI, PC; IOZI, RN; CAÑZARES, KAL; TRAVASSOS, LH; GOTO, R. 1997. Influência do intervalo de semeadura na sobrevivência e na qualidade de mudas de pepino enxertado em abóbora. Actas de Horticultura 16: 33-37.

VIDA, JB; ZAMBOLIM, L; TESSMANN, DJ; BRANDÃO FILHO, JUT; VERZIGNASSI, JR; CAIXETA, MP. 2004. Manejo de doenças de plantas em cultivo protegido. Fitopatologia Brasileira 29: 355-372.

VIEIRA JÚNIOR, GM; ROCHA, CQ; RODRIGUES, TS; HIRUMA-LIMA, CA; VILEGAS, W. 2015. New steroidal saponins and antiulcer activity from Solanum paniculatum L. Food Chemistry 186: 160-167.

ZEIST, AR; RESENDE, JTV; GIACOBBO, CL; FARIA, MDR; DIAS, DM. 2017. Graft takes of tomato on other solanaceous plants. Caatinga 30: 513-520. 